\title{
PERKEMBANGAN DAN PEMANFAATAN TEKNOLOGI INFORMASI DALAM PENYELENGGARAAN PENDIDIKAN JARAK JAUH
}

Oleh: Edy Mulyana \& Asep Saepudin *

\section{Abstrak}

Walaupun istilah teknologi informasi dan sistem informasi seringkali dipertukarkan penggunaannya, namun keduanya memiliki nuansa arti yang sama, yaitu bagaimana sebuah organisasi berusaha untuk menggunakan perangkat komputer, aplikasi, dan sarana telekomunikasi untuk meningkatkan kinerjanya secara signifikan. Ditinjau dari segi pengertiannya, sistem informasi dapat dianalogikan sebagai sebuah permintaan (demand), dimana kebutuhan akan sarana pengolahan data dan komunikasi yang cepat dan murah. Sedangkan teknologi informasi merupakan jawaban (supply) terhadap kebutuhan tersebut dalam bentuk penciptaan produk-produk berbaru teknologi perangkat keras dan perangkat lunak.

Teknologi Informasi sebagai sebuh alat dapat digunakan pada berbagai bidang dan unit kerja. Pemanfaatan Teknologi informasi pada bidang pendidikan, selain efektif digunakan pada program pendidikan jarak jauh (distance educational) juga memenuhi karakteristik sebagai sebuah inovasi bagi pengembangan pendidikan yang relatif ajeg baik aspek: relative advantage, compability, Complexity, Triability, maupun Obsevability.nya.

*) Edy Mulyana, ST., MT dan Asep Saepudin, M.Pd., adalah Staf Pengajar Sekolah Tinggi Manajemen Informatika dan Komputer Mardira Indonesia 


\section{PENDAHULUAN}

Sudah tidak dapat dipungkiri lagi bahwa kemajuan perkembangan komputer dan telekomunikasi telah merubah cara hidup masyarakat di dunia dalam menjalankan aktivitas sehari-hari. Keberadaan dan peranan teknologi informasi di segala sektor kehidupan tanpa sadar telah membawa dunia memasuki era baru globalisasi lebih cepat dari yang dibayangkan semula. Dampaknya tidak hanya berpengaruh pada sisi makro ekonomi dan politik masing-masing negara yang dipengaruhinya, tetapi lebih jauh telah merasuki aspek-aspek sosial budaya manusia termasuk bidang pendidikan.

Tidak berlebihan jika dikatakan bahwa perkembangan komputer telah membawa dunia ke sebuah era baru: abad informasi. Dari sekian banyak sektor kehidupan manusia yang dipengaruhi oleh kehadiran teknologi informasi, organisasi atau institusi pendidikan merupakan entiti yang paling banyak mendapatkan manfaat. Bagi dunia pendidikan, sistem informasi dan teknologi informasi tidak hanya berfungsi sebagai sarana pendukung untuk meningkatkan kinerja institusi dari waktu ke waktu, tetapi lebih jauh lagi telah menjadi senjata utama dalam mengembangkan mutu sumber daya manusia.

\section{KONSEP TEKNOLOGI INFORMASI DAN SISTEM INFORMASI}

Istilah 'teknologi informasi' mulai dipergunakan secara luas di pertengahan tahun 80-an. Teknologi ini merupakan pengembangan dari teknologi komputer yang dipadukan dengan teknologi telekomunikasi. Definisi kata 'informasi' sendiri secara internasional telah disepakati sebagai 'hasil dari pengolahan data' yang secara prinsip memiliki nilai atau value yang lebih dibandingkan dengan data mentah. Komputer merupakan bentuk teknologi informasi pertama (cikal bakal) yang dapat melakukan proses pengolahan data menjadi informasi. Dalam kurun waktu yang kurang lebih sama, kemajuan teknologi telekomunikasi terlihat sedemikian pesatnya, sehingga telah mampu membuat dunia menjadi terasa lebih kecil mereduksi ruang dan waktu (time and space). Dari sejarah ini dapat 
disimpulkan bahwa yang dimaksud dengan teknologi informasi adalah suatu teknologi yang berhubungan dengan pengolahan data menjadi informasi dan proses penyaluran data/informasi tersebut dalam batasbatas ruang dan waktu.

Sedangkan sistem informasi merupakan suatu kumpulan dari komponenkomponen dalam organisasi yang berhubungan dengan proses penciptaan dan pengaliran informasi. Dalam hal ini, teknologi informasi hanya merupakan salah satu komponen kecil saja. Komponen komponen lainnya adalah: proses dan prosedur, struktur organisasi, sumber daya manusia, produk, pelanggan, supplier, rekanan, dan lain sebagainya. Secara teori, di satu titik ekstrim, suatu sistem informasi yang baik belum tentu harus memiliki komponen teknologi informasi (lihat perusahaanperusahaan pengrajin kecil dengan omset milyaran); sementara di titik ekstrim yang lain, komputer memegang peranan teramat sangat penting dalam penciptaan produk (perhatikan perusahaan manufakturing Jepang yang mempekerjakan robot untuk seluruh proses perakitan). Jadi, kehandalan suatu sistem informasi dalam perusahaan atau organisasi terletak pada keterkaitan antar komponen-komponen yang ada, sehingga dapat dihasilkan dan dialirkan suatu informasi yang berguna (akurat, terpercaya, detil, cepat, relevan, dsb.) untuk lembaga yang bersangkutan.

\section{PERKEMBANGAN TEKNOLOGI INFORMASI}

Tidak dapat disangkal bahwa salah satu penyebab utama terjadinya era globalisasi yang datangnya lebih cepat dari dugaan semua pihak adalah karena perkembangan pesat teknologi informasi. Implementasi internet, electronic commerce, electronic data interchange, virtual office, telemedicine, intranet, dan lain sebagainya telah menerobos batas-batas fisik antar negara. Penggabungan antara teknologi komputer dengan telekomunikasi telah menghasilkan suatu revolusi di bidang sistem informasi. Data atau informasi bahan belajar yang pada jaman dahulu harus memakan waktu berhari-hari untuk diolah sebelum dikirimkan ke sisi lain di dunia, saat ini dapat dilakukan dalam hitungan detik. 
Menurut Dr. Richardus Eko Indrajit (2004) secara garis besar, ada tiga periode atau era perkembangan sistem informasi, yang dimulai dari pertama kali diketemukannya komputer hingga saat ini. Ketiga era tersebut yakni era komputerisasi, era teknologi informasi, dan era globalisasi informasi, terjadi tidak hanya karena dipicu oleh perkembangan teknologi komputer yang sedemikian pesat, namun didukung pula oleh teori-teori baru mengenai manajemen modern. Ahli-ahli manajemen dan organisasi seperti Peter Drucker, Michael Hammer, Porter, sangat mewarnai pandangan manajemen terhadap teknologi informasi di era modern.

\section{ERA KOMPUTERISASI}

Periode ini dimulai sekitar tahun 1960-an ketika mini computer dan mainframe diperkenalkan perusahaan seperti IBM ke dunia industri. Kemampuan menghitung yang sedemikian cepat menyebabkan banyak sekali perusahaan yang memanfaatkannya untuk keperluan pengolahan data (data processing). Pemakaian komputer di masa ini ditujukan untuk meningkatkan efisiensi, karena terbukti untuk pekerjaan-pekerjaan tertentu, mempergunakan komputer jauh lebih efisien (dari segi waktu dan biaya) dibandingkan dengan mempekerjakan berpuluh-puluh staf pegawai untuk hal serupa. Pada era tersebut, belum terlihat suasana kompetisi yang sedemikian ketat. Jumlah lembaga pendidikan atau perusahaan yang memanfaatkan teknologi ini pun masih relatif sedikit. Kebanyakan dari perusahaan-perusahaan besar secara tidak langsung "memonopoli pasar-pasar tertentu, karena belum ada pesaing yang berarti. Hampir semua perusahaan-perusahaan besar yang bergerak di bidang infrastruktur (listrik dan telekomunikasi) dan pertambangan pada saat itu membeli perangkat komputer untuk membantu kegiatan administrasinya sehari-hari. Keperluan organisasi pada lembaga pendidikan dan atau perusahaan yang paling banyak menyita waktu. Komputer pada saat itu adalah untuk administrasi back office, terutama yang berhubungan dengan akuntansi dan keuangan. Di pihak lain, kemampuan mainframe untuk melakukan perhitungan rumit juga dimanfaatkan lembaga pendidikan dan perusahaan untuk membantu menyelesaikan problem-problem teknis operasional, seperti simulasisimulasi perhitungan. 


\section{ERA TEKNOLOGI INFORMASI}

Kemajuan teknologi digital yang dipadu dengan telekomunikasi telah membawa komputer memasuki masa-masa "revolusi"-nya. Di awal tahun 1970-an, teknologi PC (Personal Computer) mulai diperkenalkan sebagai alternatif pengganti mini computer. Dengan seperangkat komputer yang dapat ditaruh di meja kerja (desktop), seseorang dapat memperoleh data atau informasi yang telah diolah oleh komputer (dengan kecepatan yang hampir sama dengan kecepatan mini computer, bahkan mainframe). Kegunaan komputer tidak hanya untuk meningkatkan efisiensi, namun lebih jauh untuk mendukung terjadinya proses pembelajaran atau proses kerja yang lebih efektif. Tidak seperti halnya pada era komputerisasi dimana komputer hanya menjadi "milik pribadi" Divisi EDP (Electronic Data Processing), di era kedua ini setiap individu di organisasi lembaga pendidikan dan perusahaan dapat memanfaatkan kecanggihan komputer, seperti untuk mengolah database, spreadsheet, maupun data processing (end-user computing).

Pemakaian komputer kemudian semakin marak, terutama didukung dengan alam kompetisi yang telah berubah dari monompoli menjadi pasar bebas. Secara tidak langsung, institusi baik berupa lembaga pendidikan, perusahaan maupun pemerintahan yang telah memanfaatkan teknologi komputer sangat efisien dan efektif dibandingkan instansi yang sebagian prosesnya masih dikelola secara manual. Pada era inilah komputer memasuki babak barunya, yaitu sebagai suatu fasilitas yang dapat memberikan keuntungan kompetitif bagi institusi, terutama yang bergerak di bidang pelayanan atau jasa seperti lembaga pendidikan.

Teori-teori manajemen organisasi modern secara intensif mulai diperkenalkan di awal tahun 1980-an. Salah satu teori yang paling banyak dipelajari dan diterapkan adalah mengenai manajemen perubahan (change management). Hampir di semua kerangka teori manajemen perubahan ditekankan pentingnya teknologi informasi sebagai salah satu komponen utama yang harus diperhatikan oleh perusahaan yang ingin menang dalam persaingan bisnis. Tidak seperti pada kedua era sebelumnya yang lebih menekankan pada unsur teknologi, pada era manajemen perubahan ini yang lebih ditekankan adalah sistem informasi, dimana komputer dan 
teknologi informasi merupakan komponen dari sistem tersebut. Kunci dari keberhasilan perusahaan di era tahun 1980-an ini adalah penciptaan dan penguasaan informasi secara cepat danc akurat. Informasi di dalam perusahaan dianalogikan sebagai darah dalam peredaran darah manusia yang harus selalu mengalir dengan teratur, cepat, terus-menerus, ke tempat-tempat yang membutuhkannya (strategis).

Ditekankan oleh beberapa ahli manajemen, bahwa lembaga yang menguasai informasilah yang memiliki keunggulan kompetitif di dalam lingkungan makro. Di dalam periode ini, perubahan secara filosofis terjadi pada lembaga pendidikan atau perusahaan yang dalam perkembangnnya merubah lembaga pendidikan dan perusahaan tradisional ke lembaga pendidikan dan perusahaan modern. Pada dasarnya, seorang pelanggan atau orang tua siswa dalam memilih lembaga pendidikan atau jasa yang dibutuhkannya, akan mencari sekolah atau perusahaan yang menawarkan jasa tersebut: cheaper (lebih murah), better (lebih baik), dan faster (lebih cepat). Di sinilah peranan sistem informasi sebagai komponen utama dalam memberikan keunggulan kompetitif bagi lembaga pendidikan dan perusahaan. Oleh karena itu, kunci dari kinerja lembaga pendidikan atau perusahaan adalah pada proses yang terjadi baik di dalam lembaga pendidikan atau perusahaan (back office) maupun yang langsung bersinggungan dengan pelanggan (front office).

Untuk itu, Tidak heran bahwa di era tahun 1980-an sampai dengan awal tahun 1990-an terlihat banyak sekali perusahaan yang kemudian diikuti banyak lembaga pendidikan tinggi melakukan BPR (Business Process Reengineering), re-strukturisasi, implementasi ISO-9000, implementasi TQM, instalasi dan pemakaian sistem informasi korporat (SAP, Oracle, BAAN), dan lain sebagainya. Utilisasi teknologi informasi terlihat sangat mendominasi dalam setiap program manajemen perubahan yang dilakukan perusahaan-perusahaan.

\section{ERA GLOBALISASI INFORMASI}

Belum banyak buku yang secara eksplisit memasukkan era terakhir ini ke dalam sejarah evolusi teknologi informasi. Fenomena yang terlihat 
adalah bahwa sejak pertengahan tahun 1980-an, perkembangan di bidang teknologi informasi (komputer dan telekomunikasi) sedemikian pesatnya, sehingga kalau digambarkan secara grafis, kemajuan yang terjadi terlihat secara eksponensial. Ketika sebuah seminar internasional mengenai internet diselenggarakan di San Fransisco pada tahun 1996 (Indrajit, 2004) para praktisi teknologi informasi yang dahulu bekerja sama dalam penelitian untuk memperkenalkan internet ke dunia industri pun secara jujur mengaku bahwa mereka tidak pernah menduga perkembangan internet akan menjadi seperti ini. Ibaratnya mereka melihat bahwa yang ditanam adalah benih pohon ajaib, yang tiba-tiba membelah diri menjadi pohon raksasa yang tinggi menjulang. Sulit untuk ditemukan teori yang dapat menjelaskan semua fenomena yang terjadi sejak awal tahun 1990an ini, namun fakta yang terjadi dapat disimpulkan sebagai berikut:

Tidak ada yang dapat menahan lajunya perkembangan teknologi informasi. Keberadaannya telah menghilangkan garis-garis batas antar negara dalam hal flow of information. Tidak ada negara yang mampu untuk mencegah mengalirnya informasi dari atau ke luar negara lain, karena batasan antara negara tidak dikenal dalam virtual world of computer. Penerapan teknologi seperti LAN, WAN, GlobalNet, Intranet, Internet, Ekstranet, semakin hari semakin merata dan membudaya di masyarakat. Terbukti sangat sulit untuk menentukan perangkat hukum yang sesuai dan terbukti efektif untuk menangkal segala hal yang berhubungan dengan penciptaan dan aliran informasi. Lembaga dan program pedidikan pun sudah tidak terikat pada batasan fisik lagi. Melalui virtual world of computer, seseorang dapat mencari sumber belajar di seluruh lapisan masyarakat dunia yang terhubung dengan jaringan internet.

Sulit untuk dihitung besarnya akses informasi yang mengalir bebas melalui jaringan internet. Transaksi-transaksi kerjasama atau kontrak belajar dapat dengan mudah dilakukan di cyberspace melalui electronic education. Tidak jarang lembaga pendidikan kaliber dunia yang akhirnya harus mendefinisikan kembali visi dan misi program pendidikannya, terutama yang bergelut di bidang teknologi. Kemudahan-kemudahan yang ditawarkan perangkat canggih teknologi informasi telah merubah mindset pengelolaan pendidikan. 
Dari keempat era di atas, terlihat bagaimana alam kompetisi dan kemajuan teknologi informasi sejak dipergunakannya komputer dalam program pendidikan hingga saat ini terkait erat satu dan lainnya. Memasuki abad informasi berarti memasuki dunia dengan teknologi baru, teknologi informasi. Mempergunakan teknologi informasi seoptimum mungkin berarti harus merubah mindset. Merubah mindset merupakan hal yang teramat sulit untuk dilakukan, karena pada dasarnya "people do not like to change". Paling tidak, hal yang harus ada terlebih dahulu di setiap individu adalah kemauan untuk berubah. Tanpa "willingness to change", sangat mustahillah kita dapat memanfaatkan teknologi informasi untuk membangun proigram pendidikan nasional dalam kancah internasional.

\section{TEKNOLOGI INFORMASI DALAM PENDIDIKAN JARAK JAUH}

\section{a. Kajian Filosofis}

Secara filosofis, pendidikan adalah hak setiap anggota masyarakat, dan pemerintah berkewajiban menyelenggarakan pendidikan dalam rangka mencerdaskan kehidupan bangsa. Proses pendidikan tidak dibatasi untuk satu wilayah atau masyarakat tertentu, tapi harus dirasakan oleh seluruh anggota masyarakat di berbagai daerah di Indonesia secara merata dalam kesempatannya maupun kualitasnya.

Berdasarkan data empirik, bahwa pada jenjang dan jalur pendidikan yang saat ini proses belajar mengajarnya relatif konvensional (tatap muka), sesungguhnya menghadapi banyak keterbatasan dan sudah tidak lagi mampu memenuhi kebutuhan pendidikan untuk masyarakat yang semakin kompleks dan tersebar. Penulis berasumsi bahwa, dengan diselenggarakannya program pendidikan jarak jauh seperti Program Belajar paket A dan Paket B, SMP terbuka yang didirikan pada tahun 1979, Universitas Terbuka sejak tahun 1984, serta pendidikan guru tertulis pada tahun 1955, dan program pendidikan dan pelatihan jarak jauh di berbagai departemen, termasuk usaha menuntaskan program Wajar 9 tahun dengan memakai system pendidikan jarak jauh, adalah fakta bahwa pendidikan konvensional 
(tatap muka) tak mampu lagi memenuhi kebutuhan pendidikan masyarakat hampir disemua jenis dan jenjang pendidikan.

Berdasarkan pertimbangan filosofis dan empirik tersebut, nampaknya pendidikan konvensional (tatap muka) yang saat ini berlangsung khususnya pada jalur pendidikan formal, sebentar lagi akan menjadi permasalahan serius. Permasalah tersebut diantaranya, pertama kendala dari pihak pemerintah yaitu terbatasnya dana untuk menambah lahan dan bangunan, gaji tenaga pengajar, serta terbatasnya sumber daya manusia yang akan menjadi pengajar pada institusi yang akan dibangun tersebut. Kedua, kendala dari pihak peserta belajar (masyarakat) itu sendiri yaitu, selain jauhnya jarak tempat tinggal dengan pusat sekolah atau kampus, juga sebagian besar diantara mereka telah bekerja dan disibukan dengan pekerjaaan kantornya, sehingga tidak bisa hadir secara teratur dalam kegiatan tatap muka.

Pada sisi lain, dengan pesatnya ilmu pengetahuan dan teknologi, serta tersedianya sumber daya manusia yang berkualitas, saat ini sudah banyak sarana dan fasilitas tekonologi komputer (seperti teknologi internet) yang memungkinkan dimanfaatkan oleh dunia pendidikan dalam kegiatan proses belajar mengajarnya (khususnya pendidikan jarak jauh), sehingga target yang diharapkan dapat tercapai secara efetif.

\section{b. Kajian Praktis-Inovasi}

Penggunaan Tekonologi Informasi dalam dunia pendidikan dimaknai sebagi sebuah inovasi. Suatu benda, alat atau teknologi dapat disebut inovasi apabila memenuhi karakteristik inovasi. Everett M. Rogers, mengembangkan teori difusi inovasi yang merinci karakteristik sebuah inovasi, yakni: relative advantage, compatibility, Complexity, Trialability, dan Observability. Dengan menggunakan karakteristik tersebut, dapat dianalisis keajegan teknologi informasi sebagai sebuah inovasi. Dibawah ini akan diuraikan gambaran karakteristik inovasi dalam penerapan teknologi informasi pada program pendidikan jarak jauh sebagia berikut: 
a. Keuntungan relatif (relative advantage),

Teknologi internet merupakan sarana yang dapat digunakan untuk berkomunikasi antar personal atau kelompok orang secara langsung, walaupun yang bersangkutan tidak hadir secara nyata. Dilihat dari aspek materi ajar, melalui pemanfaatkan teknologi informasi (Komputer), seolah-olah materi ajar dapat diakses oleh siapa saja dan kapan saja. Akses terhadap materi ajar sebenarnya dapat diatur bila dikehendaki karena tersedia fasilitas pengaman dimana hanya orang (waraga belajar) yang telah mendaftar saja yang bisa mengakses materi ajar tersebut. Kondisi ini merupakan keuntungan bagi dunia pendidikan (khususnya PLS), karena pengajar atau tutor dapat mentansfer materi ajarnya kepada warga belajar dari jarak yang jauh (tidak harus berkunjung). Selain itu setiap materi yang disampaikan melalui internet dapat diakses (dibaca) oleh banyak warga belajar dalam waktu yang bersamaan atau berbeda, sehingga warga belajar tidak diharuskan menerima materi ajar pada waktu yang dijadualkan seperti pendidikan tatap muka.

Selain secara status sosial lebih bergengsi, proses belajar mengajar dengan memanfaatkan teknologi internet sangat ekonomis, karena sangat efisien dari biaya. Alasan tersebut dikarenakan, pertama, proses belajar mengajar tidak harus memerlukan bangunan tetap seperti sekolah, kedua, bagi Totur tidak harus mengeluarkan banyak biaya untuk transfortasi atau biaya akomodasi lainnya, ketiga, bagi warga belajar tidak harus membeli modul-modul banyak.

b. Kesepadanan (compatibility),

Berkenaan dengan kesesuaian, penerapan teknologi internet tidak bertentangan dengan nilai yang berkembang dalam masyarakat, seperti nilai-nilai agama, budaya atau norma masyarakat lainnya, mengingat inovasi ini lebih bersifat individual dan hanya diakses oleh individu (warga belajar) yang berkepentingan tidak melibatkan dan atau menganggu masyarakat lain secara menyeluruh. Bahkan dengan hadirnya teknologi ini masyarkat memandang adalah 
sebuah kemajuan zaman yang harus diikuti oleh masyarakat. Hal ini terbukti dari animo masyarakat untuk mendirikian lembaga kursus serta mengikutsertakan putra-putrinya untuk kursus komputer/internet semakin tumbuh berkembang hampir disetiap wilayah.

c. Kompleksitas (Complexity),

Proses belajar mengajar dengan memanfaatkan teknologi internet, awalnya akan dianggap sukar, karena memerlukan keterampilan tersendiri yang diperoleh melalui proses belajar dan melibatkan provider tertentu. Kerumitan tersebut dapat teratasi, karena fasilitas dan sumber-sumber buku panduan belajar komputer serta lembaga-lembaga kursus sudah tersebar banyak. Selain itu, para putera-puteri anggota masyarakat (umumnya pelajar) relatif telah mengenal pengopersian komputer, dan saat ini hampir disetiap rumah telah memiliki komputer. Berkenaan dengan provider (pusat akses), hampir diseluruh Indonesia telah terjangkau banyak provider. Oleh karena itu, Bagi warga belajar memungkinkan mengakses materi ajar melalui teknologi internet.

d. Kemungkinan dapat dicoba (Trialability),

Teknologi internet yang sarananya adalah komputer merupukan barang nyata, yang dapat dicoba langsung oleh setiap warga belajar. Bahkan dapat dipelajari oleh siapa saja. Melalui proses mencoba, warga belajar dapat melihat kecanggihan komputer dalam mengolah informasi. Hal ini merupakan daya tarik tersendiri akan tercapainya difusi inovasi bagi warga belajar untuk memanfatakan teknologi komputer.

e. Kemungkinan dapat diamati (Obsevability),

Proses kerja komputer adalah proses kerja teknologi yang hasilnya dapat langsung dilihat. Warga belajar dapat mencoba memberikan masukan (input) data, kemudian komputer akan memproses dan dengan segera akan dihasilkan keluaran (output) sistem informasi hasil pengolahan data berupa printout, atau visualisasi pada display, dalam bentuk tulisan, tabulasi data, 
gambar, dan sebagainya. Hal ini meruapakan salah satu daya tarik cepatnya proses difusi inovasi penerapan teknologi internet/ komputer bagi program kegiatan belajar jarak jauh.

\section{c. Kajian Dukungan dan Hambatan}

Daya dukung dalam difusi inovasi penerapan teknologi internet pada program Pendidikan jarak jauh, diantaranya, pertama dilihat dari sofwre. Bahwa penyampain materi yang akan ditransformasikan kepada warga belajar dapat lebih efektif dan efisien, karena di Indonesia sudah banyak dibuat software pendidikan oleh para pakar komputer, walaupun tergolong pada fase "early stage". Saat ini suda banyak software pendidikan yang bermutu tinggi dan beberapa diantaranya buatan luar negeri. Beberapa contoh software pendidikan yang dikenal diantaranya: computer assisted instruction (CAl), yang umumnya software ini sangat baik untuk keperluan remedial. intelligent computer assited instructional (ICAL), dapat digunakan untuk material tau konsep. Computer assisted training (CAT), computer assisted design (CAD), computer assisted media (CAM), dan lain-lain. Hampir dapat dipastikan bahwa setiap kantor telah memiliki dan menggunakan komputer. Kedua, Dilihat dari kesiapan masyarakat, Saat ini pada setiap keluarga, komputer sudah menjadi fasilitas biasa dan dapat dioperasikan oleh hampir semua anggota keluarga. Jumlah keluarga yang mempunyai komputer menunjukan peningkatan sebagai hasil kemajuan dari perkembangan ekonomi. Ini berarti bahwa jumlah masyarakat yang mempunyai akses terhadap komputer meningkat dari waktu kewaktu. Oleh arena itu, program pendidikan jarak jauh dengan berbasis komputer/internet dapat dikembangkan untuk kelompok (masyarakat) ini.

Mengingat negara bertanggung jawab untuk mencerdaskan kehidupan bangsa, maka negara tentu yang akan menyediakan materi ajar dengan mempekerjakan pakar yang mempunyai dedikasi tinggi untuk memajukan pendidikan di Indonesia. Selama ini pemerintah telah banyak menyediakan materi jarar. Mahalanya biaya honor dan pembuatan materi ajar bukan masalah, karena dapat dijustifikasi, apabila materi ajar tersebut dapat dipakai oleh segenap anggota masyarakat di Indonesia 
Hambatan yang mungkin dihadapai dalam inovasi tersebut, digambarakn Evert M. Rogers yang oleh Ibrahim (1988) di diklasifikasikan dalam enam (6) hambatan inovasi yaitu, Estimasi, konflik, inovasi tidak berkembang (macet), finansial, penolakan kelompok tertentu, kurangnya hubungnan sosial. Dari keenam faktor tersebut, ada dua (2) hambatan dalam inovasi penerapan teknologi intrenet ini yaitu, macetnya inovasi dan keterbatasan finansial. Macetnya inovasi dikarenakan keterbatasan warga belajar untuk mengopersikan komputer/internetnya dalam mengakses bahan ajar (faktor internal). Oleh karena itu perlu ada aksi untuk menyiapkan masyarakat (ready for lerning), yaitu dengan cara melibatkan para penyuluh lapangan dari departemen terkait, mislanya penyuluh pertanian, penyuluh industri, aparat pemerintah setempat dan sebagainya. Mereka ini petugas yang telah terlatih dan mengetahui materi ajar yang tersedia dan cara akses atau mendapatkannya. Mereka bertanggungjawab membantu kelompok masyarakat termasuk mengkomunikasikan materi ajar yang tidak dipahami masyarakat sehingga dapat mempelajarinya dalam waktu tertentu. Sedangkan keterbatasan finansial (faktor eksternal), akan terjadi karena inovasi ini perlu biaya banyak untuk menyediakan sarana komputer termasuk iuran wajib kepada provider. Untuk mengatasi hal tersebut, setiap per satu komputer diakses oleh satu kelompok warga belajar.

Jaringan internet merupakan salah satu jenis jaringan yang populer dimanfaatkan, karena internet merupakan teknologi informasi yang mampu menghubungan komputer di seluruh dunia, sehingga memungkinkan informasi dari berbagai jenis dan bentuk informasi dapat dipakai secara bersama-sama. Program ini optimis akan berjalan dengan baik, karena saat ini telah banyak perusahaan swasta di Indonesia yang menyediakan jasa sambungan internet, misalnya Indolnternet, Radnet, D-Net, Idola, dan lain-lain.

Sebagai ilustrasi, kita dapat mengadopsi pola PT Pos Indonesia yang yang pada beberapa tahun lalu menjadi penyedia jasa sambungan ke internet (Wasantara-Net) yang membuka cabang disetiap kota, 
yang kemudian menjadi pengembangan Nusantara 21. Nusantara 21 adalah jalan raya lintasan informasi yang menghubungkan seluruh kawasan nusantara dengan bandwidth yang sangat besar, sehingga memungkinkan pertukaran informasi dalam berbagai bentuk (teks, grafis, suara dan video) dapat terjadi dengan cepat.

Penerapan teknologi komputer dalam pendidikan, dapat diterapkan melalui beberapa kategori yaitu. Pertama, karena alasan masyarakat (warga belajar) sudah memiliki komputer sendiri, maka dapat dikembangkan Paket belajar Personal-Interaktif. Paket ini dilakukan dengan cara memanfaatkan software pendidikan seperti; Computer Assisted Instructional (CAI) atau Computer-Based Training (CBT). Pada pemanfaatan jenis ini, informasi atau materi ajar dikemas dalam suatu software. Peserta belajar dapat belajar dengan cara menjalankan program komputer atau perangkat lunak tersebut di komputer secara mandiri dan di lokasi masing-masing. Melalui paket program belajar ini peserta dapat melakukan simulasi atau juga umpan balik kepada peserta ajar tentang kemajuan belajarnya. Kedua, karena alasan negara Indonesia terdiri atas ribuan pulau yang tersebar dalam wilayah yang sangat luas, serta dihuni oleh lebih dari 200 juta penduduk dengan distribusi secara tidak homogen. Kondisi ini memang disadari kendala ketika akan diterapkan sistem pendidikan konvensional (tatap muka). Maka teknologi internet yang mungkin diterapkan untuk kondisi tersebut adalah melalui jaringan internet.

Ada beberapa alternatif paradigma pendidikan melalui internet ini yang salah satunya adalah system "dot.com educational system" (Kardiawarman, 2000). Paradigma ini dapat mengitegrasikan beberapa system seperti; (1) paradigma virtual teacher resources, yang dapat mengatasi terbatasnya jumlah tutor/instruktur yang berkualitas, sehingga warga belajar tidak harus secara intensif memerlukan dukungan tutor, karena peranan instruktur/tutor maya (virtual teacher) dan sebagian besar diambil alih oleh system belajar tersebut. (2) virtual school system, yang dapat membuka peluang 
menyelenggarakan pendidikan tinggi yang tidak memerlukan ruang dan waktu. Keunggulan paradigma ini daya tampung siswa tak terbatas. Warga belajar dapat melakukan kegiatan belajar kapan saja, dimana saja, dan darimana saja. (3) paradigma cyber educational resources system, atau dot com leraning resources system. Merupakan pedukung kedua paradigma di atas, dalam membantu akses terhadap artikel atau jurnal elektronik yang tersedia secara bebas dan gratis dalam internet.

Semua paradigma tersebut di atas dapat diintegrasikan kedalam suatu system pendidikan jarak jauh (distance educational) dengan pemanfaatan teknologi internet. Salah satu bentuk pemanfatan teknologi internet pada pendidikan jarak jauh adalah pengajaran berbasis Webyang dikenal dengan istilah e-Learning. Melalui media ini proses belajar dapat dijalankan secara on-line atau di-download. Untuk keperluan off-line. Warga belajar (adopter) dapat mengakses system kapan saja dibutuhkan dan sesering mungkin (time independence), tidak terbatas pada jam belajar dan tidak tergantung pada tempat (place independence). Fungsi lain yang dapat digunakan untuk proses belajar tersebut melalui e-mail atau grup diskusi, yang dapat berinteraksi dan mengirimkan naskah secara electronic. Ketiga, karena alasan untuk kesamaan mutu dalam memperolah materi, dikembangkan paket belajar terdistribusi. Materi ajar dapat dikemas dalam bentuk Webpage, ataupun program belajar interaktif (CAl atau CBT). Materi belajar kemudian di tempatkan disebuah server yang tersambung ke internet sehingga dapat diambil oleh warga belajar baik memakai Web-Browserataupun File Transport Protocol (aplikasi pengiriman file). 


\section{DAFTAR PUSTAKA}

Asep Saepudin. 2001. Alih IImu dan Teknologi dalam Pendidikan. Jurnal Teknodik Pustekom Depdiknas. No. 9/Okt/2001.

Alexander,S.: "Teaching and Learning on the Word Wide Web", http:/ /www.scu.edu.au/Ausweb95/papers/education/alexander.

Everett M. Rogers. 1983. Diffusion of Innovasion. The Free Press A Division of MacMillan Publishing Co. Inc. New York.

Ibrahim. 1998. Inovasi Pendidikan. Jakarta; Dirjen Dikti Indrajit E.R, (2004). Sistem Informasi. Bandung: Makalah Seminar. Kardiawan . 2000. Pendidikan Berbasis Komputer. Mimbar Pendidikan. No. 4 tahun XiX. UPI Bandung. Mulyani Sumantri. 2000. Inovasi Pendidikan (Catatan Perkulaihan). 